\title{
REPRINTS AVAILABLE
}

\section{Business History Review}

Formerly: Bulletin of the Business

Historical Society, Boston

Vols, 1-43 and Gen. Ind. 1-30. Boston,

Mass., 1926-1969

Vols. 1-30 (in 15 units) ${ }^{\circ}$

Vols. $31-43$

General Index

General Index 28-30

- Vols. 1-24 reprinted in units as follows:

$1 / 3(1926-29)$; 4/6(1930-32); 7/9(1933-35);

$10 / 12(1936-38) ; 13 / 15(1939-41) ; 16 / 18(1942-44)$;

19/20(1945-46); $21 / 22(1947-48) ; 23 / 24(1949-50)$.

Journal of Economic and Business History

Vols. 1-4(all publ.). Cambridge, Mass.,

1928/29-1931/32.

cloth $\$ 164.00$

paper $\$ 140.00$

per vol. paper $\$ 35.00$

Order from:

\section{KRAUS REPRINT CO}

A U.S. Division of Kraus-Thomson Organization Limited

Route 100

Millwood, New York 10546

\section{This publication is available in microform.}

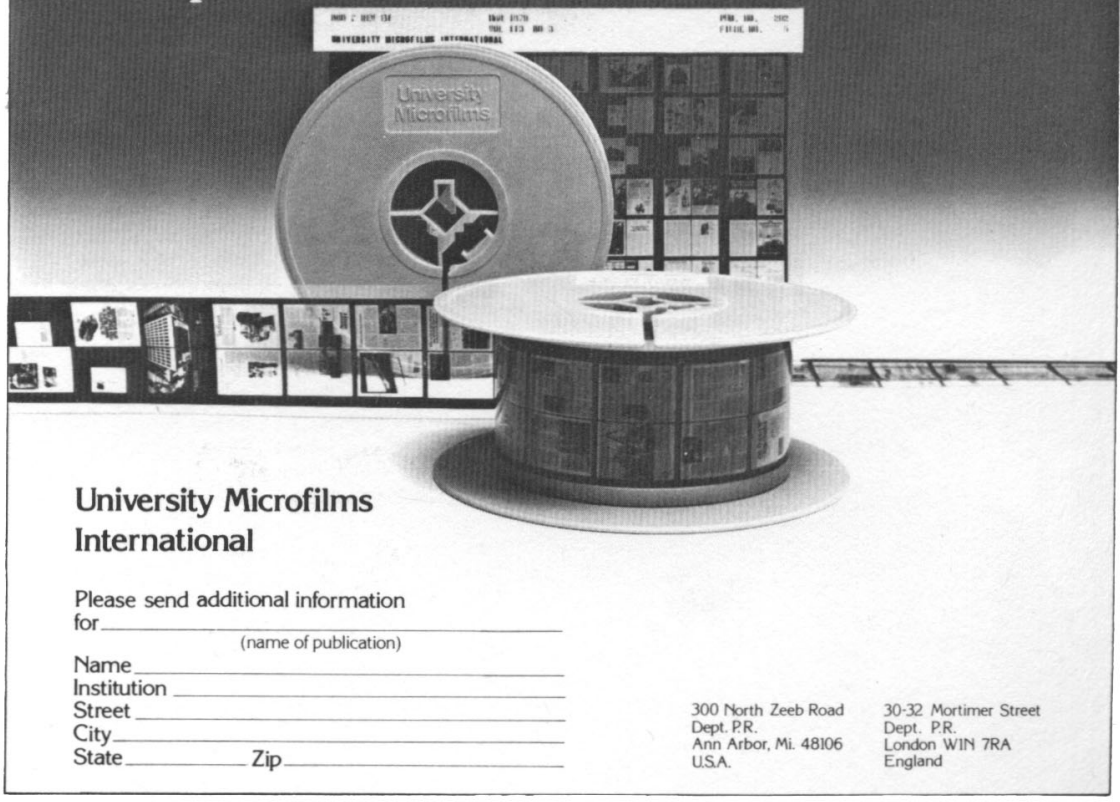




\section{Newcomen Awards in Business History}

For the best article published in the Business History Review during the previous year the Society will award a prize of $\$ 300$ and a scroll. For the best article published in the Business History Review during the previous year by a graduate student or a recent $\mathrm{Ph}$.D. who has not published a book in business history, the Society will award a special prize of $\$ 150$ and a scroll. Criteria for selection include: originality, value, breadth, and interest of contribution, quality of research materials and methods, and quality of presentation.

Winners will be selected by a panel of judges consisting of the editors and the members of the advisory board of the Business History Review, none of whom shall be eligible to receive a prize. The awards are administered by the editorial office of the Review. No special prize will be awarded in years when, in the opinion of the judges, no eligible article suitable for the prize was published, and no person may be awarded both prizes in any one year.

\section{ANNOUNCING THREE AWARDS}

IN BUSINESS HISTORY

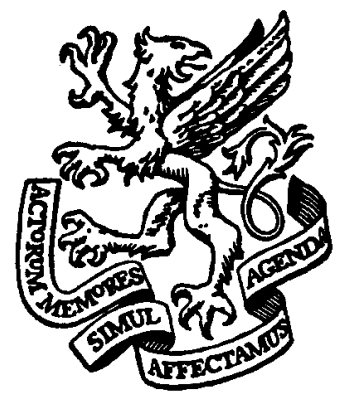

\section{PRESENTED BY THE NEWCOMEN SOCIETY IN NORTH AMERICA}

\section{Thomas Newcomen Book Award in Business History}

The Newcomen Society in North America, in cooperation with the Business History Review, will award in 1982 the seventh in a series of triennial prizes consisting of $\$ 1000$ and a scroll for the best book on the history of business published in the United States during the years 1979-1981. "Business history" is defined in its broadest sense to include not only the history of firms or industries, but books tracing interactions of businessmen, analyses of business philosophy or behavior, and studies of the adjustment of businesses and businessmen to their economic, political, and social environments. Criteria for selection will include contribution to knowledge, depth of analysis, soundness of reasoning, clarity of style and organization, and general readability and format.

Judges for the 1982 award are Dr. Albro Martin, Oglesby Professor of the American Heritage, Bradley University; Dr. Alfred D. Chandler, Jr., Straus Professor of Business History, Harvard Graduate School of Business Administration; and Mr. Stanley van den Heuvel, The Newcomen Society in North America. 